\title{
Pemberdayaan Petani Jagung di Kelurahan Sedau Kecamatan Singkawang Selatan melalui Pelatihan Pembuatan Briket dari Sisa Hasil Panen dan Pengolahan Jagung
}

\author{
Muhammad Susilo ${ }^{1)}$, Muhammad Ali ${ }^{2}$, Ichsan ${ }^{3)}$, Dwi I. Achmad ${ }^{4)}$, Jaini Fakhrudin ${ }^{5)}$, Th. Chandra \\ Wasis $^{6)}$, Revi Sesario ${ }^{7)}$, Lamria Mangunsong ${ }^{8)}$, Lidia Chronika ${ }^{9)}$, Dodi Iskandar ${ }^{10)}$ \\ 12/234)5(6)708(9)10) Jurusan Teknologi Pertanian, Politeknik Negeri Pontianak, Indonesia
}

Corresponding Author: Muhammad Susilo,muhammadsusilo@gmail.com

\begin{abstract}
Abstrak: Potensi pengembangan produk dari limbah/sisa panen dan pengolahan jagung di Kelurahan Sedau cukup tinggi. Jumlah rata-rata produksi jagung yang mencapai 4,3 ton/Ha menyisakan sekitar 37\% limbah yang tidak masyarakat manfaatkan sedangkan jika hasil panen hanya digunakan bijinya saja, maka limbah yang dihasilkan beratnya 1,5 kali dari berat biji yang dihasilkan. Limbah ini mengandung hemiselulosa dan lignin yang tinggi, sehingga berpotensi untuk dijadikan sebagai briket. Metode yang digunakan dalam kegiatan ini yaitu penyuluhan, praktek pembuatan briket dan evaluasi hasil kegiatan pada khalayak sasaran di Koperasi Kelompok Tani JAS-B. Hasil briket yang dihasilkan lebih baik teksturnya dibandingkan briket dari bahan baku lainnya. Seluruh peserta merasa tertarik untuk mencoba membuat produk briket dari limbah jagung, sebanyak 86\% peserta baru mengetahui informasi mengenai briket saat pelatihan oleh Tim PPM Politeknik Negeri Pontianak (Polnep). Hasil analisis finansial dari pengolahan limbah jagung ini cukup potensial untuk meningkatkan perekonomian petani jagung di daerah Sedau.
\end{abstract}

Kata Kunci: Sedau, petani, jagung, limbah, briket

Abstract: The potency of product development from waste/crop residues and corn processing in Sedau Village is relatively high. The average amount of maize production, which reaches 4.3 tonnes/ha, leaves around $37 \%$ of the waste that the community has not utilized. In contrast, if the harvest only used the seeds, the resulting waste weighs 1.5 times the weight of the beans produced. This waste contains high hemicellulose and lignin, so it has the potency to be used as briquettes. The methods used in this activity are counseling, briquette-making practice, and evaluating the results of actions to target audiences at the JAS-B Farmer Group. The resulting briquettes have a better texture than briquettes from other raw materials. All participants felt interested in trying to make briquette products from corn waste, as many as $86 \%$ of the participants just learned information about briquettes during the training by the PPM Politeknik Negeri Pontianak (Polnep)Team. The results of the financial analysis of this maize waste processing can improve the economy of maize farmers in the Sedau area.

Keywords: Sedau, farmer, corn, waste, briquette

\section{Pendahuluan}

Kelurahan Sedau merupakan daerah yang potensial untuk dikembangkan karena kaya akan sumber daya alamnya. Kelurahan Sedau berada di Kecamatan Singkawang Selatan 
bersama 3 kelurahan lainnya. Sedau merupakan kelurahan dengan luas wilayah terluas, yaitu mencapai \pm 7.390 Ha (BPS Kota Singkawang, 2018). Mayoritas penduduk Sedau bekerja sebagai petani,baik petani tanaman pangan, hortikultura, palawija dan perkebunan. Salah satu jenis tanaman yang cukup potensial untuk dikembangkan yaitu tanaman jagung. Sedau tidak menjadi centra budidaya jagung karena penggunaan lahannya yang masih terbatas untuk lahan jagung. Namun jika ditinjau dari potensi hasil panen jagung dari lahan terbatas tersebut, produktivitas tanaman jagung di Sedau tergolong tinggi dibadingkan dengan tanaman lainnya. Dalam upaya pengembangan budidaya jagung yang lebih kompetitif, diperlukan upaya efisiensi usaha tani, baik ekonomi, mutu maupun produktivitas melalui penerapan teknologi mulai dari penentuan lokasi, penggunaan varietas, benih bermutu, penanaman, pemeliharaan, hingga penanganan panen dan pasca panen yang tepat (BPTP NAD, 2009). Hal inilah yang perlu dilakukan pada Kecamatan Sedau agar dapat mengembangkan pra penanaman, penanaman hingga panen dan pasca panennya.

Tanaman jagung umumnya dijual secara mentah, namun juga diolah menjadi produk pangan. Pendapatan petani jagung sangat dipengaruhi oleh nilai jual produk mentah atau produk pangan tersebut. Jika terbatas hanya pengolahan untuk pangan, maka setiap kali musim panen, akan menghasilkan limbah dari sisa hasil panen atau pengolahannya. Bagian tanaman jagung seperti daun, batang, dan tongkol yang biasanya dibuang atau ditinggalkan di lokasi tanam mengandung bahan organik yang dapat dimanfaatkan (Ernita dkk., 2017). Oleh karena itu, perlu adanya pengolahan lanjutan. Limbah atau hasil samping berupa kulit, batang, daun, dan tongkol jagung pascapanen tidak termanfaatkan dan hanya dibuang atau dibakar oleh masyarakat sehingga berpotensi menjadi polusi. Sementara itu, daun dan batang tanaman jagung dijadikan pakan ternak. Tongkol dan batang jagung sangat kaya akan karbohidrat jenis selulosa yang dapat diolah menjadi produk yang bermanfaat dan bernilai ekonomi untuk kehidupan manusia. Dengan adanya sentuhan teknologi, limbah tongkol dan batang jagung tersebut dapat dikembangkan menjadi suatu produk yang lebih bernilai ekonomi. Salah satunya yaitu dapat dibuat menjadi briket.

Briket arang dapat digunakan sebagai bahan bakar alternatif untuk menggantikan bahan bakar minyak dan gas dalam kegiatan industri dan rumah tangga. Briket arang merupakan bentuk energi terbarukan dari biomassa yang berasal dari tumbuhan atau tanaman yang saat ini sangat banyak tersedia di lingkungan. Limbah pertanian yang merupakan biomassa tersebut merupakan sumber energi alternatif yang melimpah dengan kandungan energi yang relatif besar. Selain itu, dengan adanya produk bernilai jual tinggi, dapat meningkatkan penghasilan petani atau masyarakat sekitar di Kelurahan Sedau, Singkawang Selatan.

Potensi pengembangan produk dari limbah/sisa panen dan pengolahan jagung di Kelurahan Sedau cukup tinggi. Selain menjual bahan mentah dan pangan dari olahan jagung, masyarakat juga dapat menjual olahan limbahnya. Jumlah rata-rata produksi jagung yang mencapai 4,3 ton/Ha menyisakan sekitar 37\% limbah yang tidak masyarakat manfaatkan, sedangkan jika hasil panen hanya digunakan bijinya saja, maka limbah yang dihasilkan beratnya 1,5 kali dari berat biji yang dihasilkan. Limbah ini mengandung hemiselulosa dan lignin yang tinggi, sehingga berpotensi untuk dijadikan sebagai briket. Briket jika dibandingkan dengan arang biasa memiliki nilai ekonomi yang lebih tinggi. Briket dapat dijadikan sebagai bahan bakar padat untuk menggantikan penggunaan bahan bakar minyak dan gas. Briket yang berkualitas baik mampu mempertahankan nyala api lebih lama dan digunakan oleh industri untuk keperluan produksinya.

Selama ini, pemanfaatan limbah sisa panen dan pengolahan jagung masih terbatas pada pembuatan produk sederhana seperti arang yang bernilai jual rendah. Perlu adanya penyuluhan dan pelatihan pembuatan produk bernilai jual tinggi seperti briket kepada Petani jagung dan 
masyarakat sekitarnya sehingga dapat meningkatkan nilai jual limbah yang tidak termanfaatkan dan dapat menambah penghasilan petani. Tujuan dari kegiatan PPM ini adalah untuk meningkatkan perekonomian masyarakat di Kelurahan Sedau dengan membuat produk berupa briket yang bernilai jual tinggi dari limbah/sisa hasil panen dan pengolahan tanaman jagung yang belum dimanfaatkan secara optimal.

\section{Metodologi}

\section{A. Penyuluhan tentang Pemanfaatan Limbah Tanaman Jagung}

Penyuluhan dilakukan di Balai Desa dengan mengundang kelompok tani Jagung Kecamatan Sedau. Penyuluhan dilakukan dengan metode presentasi dan menampilkan bahan tayang/alat peraga. Penyuluhan dilakukan untuk sosialisasi manfaat limbah pertanian khususnya limbah dari tanaman jagung dan potensi produk sampingan yang dihasilkan serta peluang bisnisnya.

\section{B. Pembuatan Briket}

B.1. Proses Karbonasi (Pengarangan)

Limbah tongkol dan batang jagung yang telah dipilih dimasukkan ke dalam drum pengarangan disusun sedemikian rupa hingga hampir penuh. Kemudian drum ditutup rapat dan api dinyalakan melalui lubang ventilasi/tempat bagian dasar drum, proses pembakaran dibiarkan sehingga semua bahan habis terbakar. Setelah dingin dilakukan pembongkaran dan arang yang dihasilkan dipisahkan dari abu sisa pembangkaran untuk proses lebih lanjut.

\section{B.2. Proses Pembuatan Briket}

Arang dari proses karbonasi digiling atau dihaluskan dan diayak kemudian ditambahkan perekat (lem kanji) yang telah disiapkan dengan perbandingan $10 \%$ bagian perekat dari berat arang dan diaduk hingga semuanya tercampur secara merata. Adonan yang sudah jadi siap untuk dicetak menjadi briket dengan bentuk kubus atau silinder dengan cara memasukkan adonan ke dalam cetakan kemudian dipress dengan alat pengepres. Briket arang yang sudah dicetak kemudian dikeringkan/dijemur di bawah sinar matahari hingga kering betul dan briket siap digunakan untuk keperluan industri/rumah tangga sebagai bahan bakar alternatif.

\section{Evaluasi Pelaksanaan PPM}

Untuk memastikan pelaksanaan PPM berjalan dengan lancar dan sesuai dengan tujuan pelaksanaan, maka perlu dilakukan evaluasi. Evaluasi pelaksanaan PPM dilakukan dalam beberapa tahap, yaitu:

\section{Evaluasi terhadap inovasi yang terserap sebelum dan sesudah pelaksanaan PPM}

Evaluasi pertama berupa kuesioner yang disebar kepada peserta PPM. Evaluasi ini dilakukan tepat sebelum dan setelah berlangsungnya kegiatan penyuluhan dan pelatihan pembuatan briket. Tujuan dari evalusi ini adalah untuk mengetahui berapa persen serapan pengetahuan dan keterampilan tentang inovasi setelah peserta mengikuti PPM serta manfaat materi yang diberikan bagi peserta. 


\section{Evaluasi Analisis Finansial Ekonomi Petani Jagung}

Evaluasi kedua dilakukan dua minggu setelah pelaksanaan PPM. Evaluasi ini bertujuan untuk memastikan keberlangsungan produksi briket oleh petani dan menganalisis finansial ekonomi petani sebelum dan setelah pelaksanaan PPM. Evaluasi ini dilakukan agar mengetahui potensi penjualan briket hasil panen dan pengolahan jagung dalam upaya peningkatan pendapatan petani jagung.

\section{Evaluasi Lanjutan}

Evaluasi ini merupakan evaluasi lanjutan terhadap keberlanjutan dan keberhasilan program. Evaluasi ini bersifat sebagai kontrol terhadap kegiatan produksi briket serta menjaga terjalinnya silaturahim serta kerjasama dengan kelompok tani jagung di Kecamatan Sedau setelah kegiatan PPM selesai. Indikator keberhasilan yaitu terbentuknya usaha tani dalam pembuatan briket dari sisa panen dan pengolahan jagung di kecamatan Sedau.

\section{Hasil dan Pembahasan}

PPM di Kelompok Tani JAS-B Kelurahan Sedau Singkawang Selatan dilaksanakan dalam beberapa kegiatan, yaitu survey kegiatan yang dilakukan pada bulan Agustus 2019, selanjutnya dilakukan persiapan kegiatan dengan menyiapkan alat dan bahan yang akan digunakan saat kegiatan yaitu di bulan Agustus dan September 2019. Kegiatan inti dari PPM ini dilaksanakan pada hari Sabtu, 21 September 2019.

Kegiatan PPM dilakukan dalam 4 tahap di lokasi pelaksanaan yaitu di di Kelurahan Sedau Singkawang Selatan. Keempat kegiatan tersebut yaitu Survey lokasi, penyuluhan, pelatihan dan evaluasi kegiatan PPM. Adapun uraian kegiatan yang telah dilaksanakan yaitu:

\section{Survey Lokasi PPM}

Survey lokasi PPM dilakukan oleh perwakilan anggota PPM. Lokasi yang dituju adalah Kelurahan Sedau Singkawang Selatan. Survey langsung dilakukan dengan bertemu dengan Bapak Lurah Sedau, yaitu Bapak Darwis. Lurah Sedau mengarahkan untuk melakukan kegiatan di kelompok tani jagung JAS-B yang diketuai oleh Bapak Naweri. Dalam kegiatan survey ini dilakukan permintaan izin pelaksanaan kegiatan PPM, persetujuan waktu pelaksanaan dan koordinasi tentang kegiatan yang akan dilakukan.

\section{Penyuluhan tentang Pemanfaatan Limbah Tanaman Jagung}

Pada hari kegiatan PPM dilaksanakan, ada 3 inti kegiatan. Kegiatan ini diawali dengan kegiatan penyuluhan tentang pemanfaatan limbah tanaman jagung. Penyuluhan dilakukan oleh Ketua Tim PPM yaitu D.U.M Susilo (lihat Gambar 1). Penyuluhan dilakukan di Depan Rumah Ketua Kelompok Tani JAS-B. Kegiatan ini mengundang anggota kelompok tani Jagung JASB Kecamatan Sedau. Penyuluhan dilakukan dengan metode presentasi langsung dengan menampilkan leaflet dan alat peraga. Penyuluhan dilakukan untuk sosialisasi manfaat limbah pertanian khususnya limbah dari tanaman jagung dan potensi produk sampingan yang dihasilkan serta peluang bisnisnya.

\section{Pelatihan Pembuatan Briket}

Kegiatan inti kedua yang dilakukan yaitu pemberian pelatihan pembuatan briket kepada anggota kelompok tani JAS-B. Dalam pelaksanaannya dilakukan beberapa tahap kegiatan sesuai prosedur dengan menggunakan peralatan yang dibawa dari Pontianak untuk diserahkan kepada kelompok tani JAS-B. Adapun tahapan kegiatan pelatihannya yaitu sebagai berikut: 


\section{Proses Karbonasi (Pengarangan)}

Limbah tongkol dan batang jagung yang telah dipilih dimasukkan ke dalam drum pengarangan disusun sedemikian rupa hingga hampir penuh. Kemudian drum ditutup rapat dan api dinyalakan melalui lubang ventilasi/tempat bagian dasar drum, proses pembakaran dibiarkan sehingga semua bahan habis terbakar. Setelah dingin dilakukan pembongkaran dan arang yang dihasilkan dipisahkan dari abu sisa pembangkaran untuk proses lebih lanjut (lihat Gambar 2).

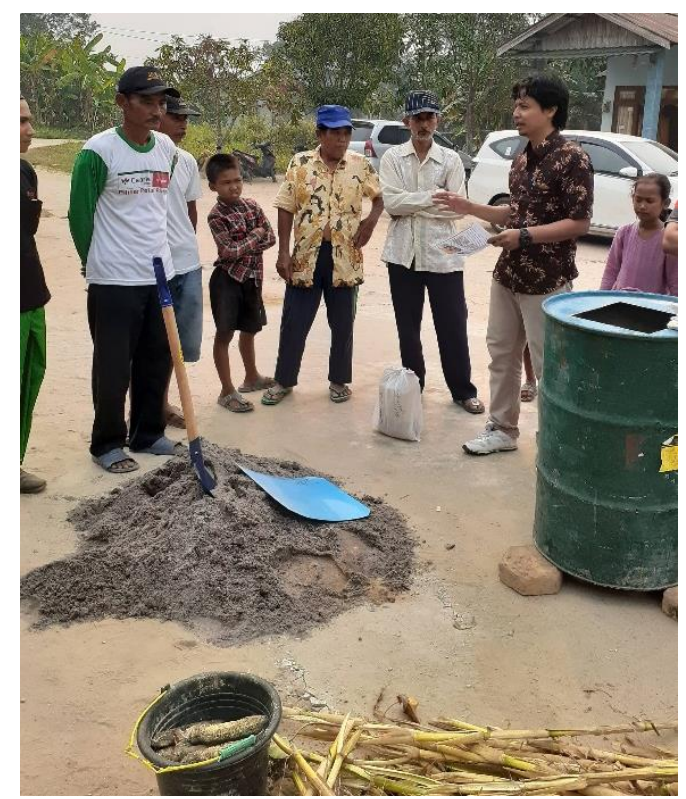

Gambar 1. Kegiatan pemberian informasi terkait pembuatan briket dari limbah sisa panen dan pengolahan jagung

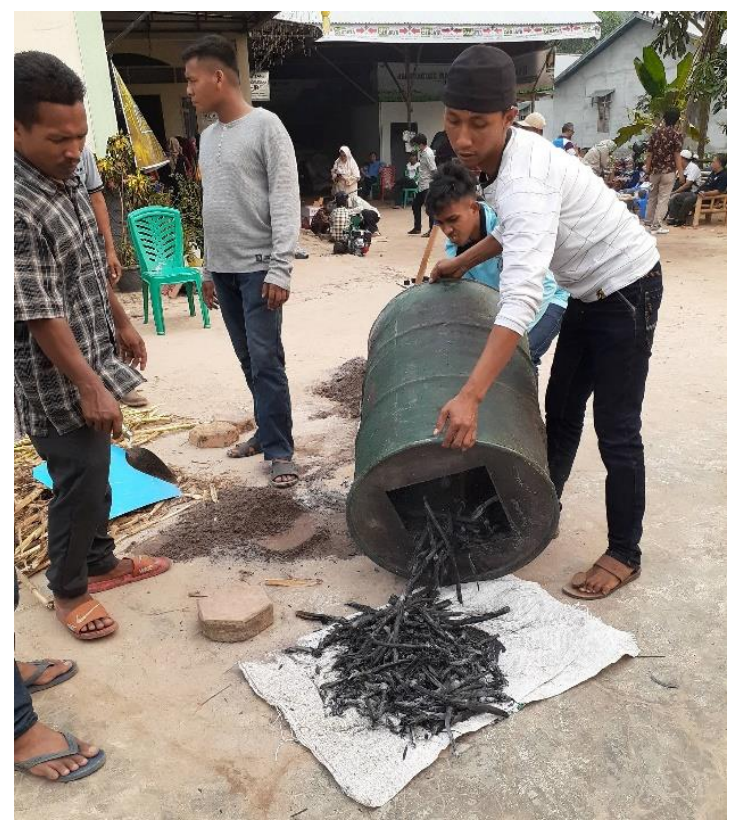

Gambar 2. Arang Hasil Pembakaran limbah Jagung

\section{Proses Pembuatan Briket}

Arang dari proses karbonasi digiling atau dihaluskan dan diayak (lihat Gambar 3) kemudian ditambahkan perekat (lem kanji) yang telah disiapkan dengan perbandingan 10\% bagian perekat dari berat arang dan diaduk hingga semuanya tercampur secara merata. Adonan 
yang sudah jadi siap untuk dicetak menjadi briket (lihat Gambar 4) dengan bentuk kubus atau silender dengan cara memasukkan adonan ke dalam cetakan kemudian dipress dengan alat pengepres. Briket arang yang sudah dicetak kemudian dikeringkan/dijemur di bawah sinar matahari hingga kering betul dan briket siap digunakan untuk keperluan industri/rumah tangga sebagai bahan bakar alternatif. Hasil briket yang kering kemudian dikemas dalam plastik transparan yang ditempel logo. Kami melakukan perbandingan dimana juga digunakan arang yang dibeli di pasar dari bahan baku kayu. Hasil yang diperoleh menunjukkan bahwa briket dari arang limbah jagung lebih baik tampilannya, dimana terlihat bahwa ukurannya lebih halus dan seragam.

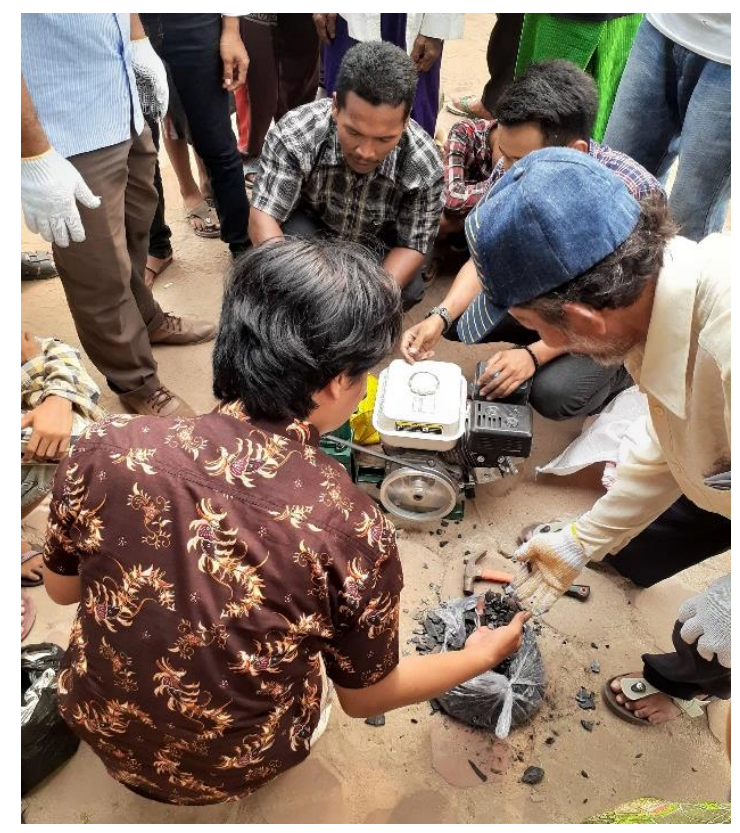

Gambar 3. Proses penghalusan arang menggunakan mesin

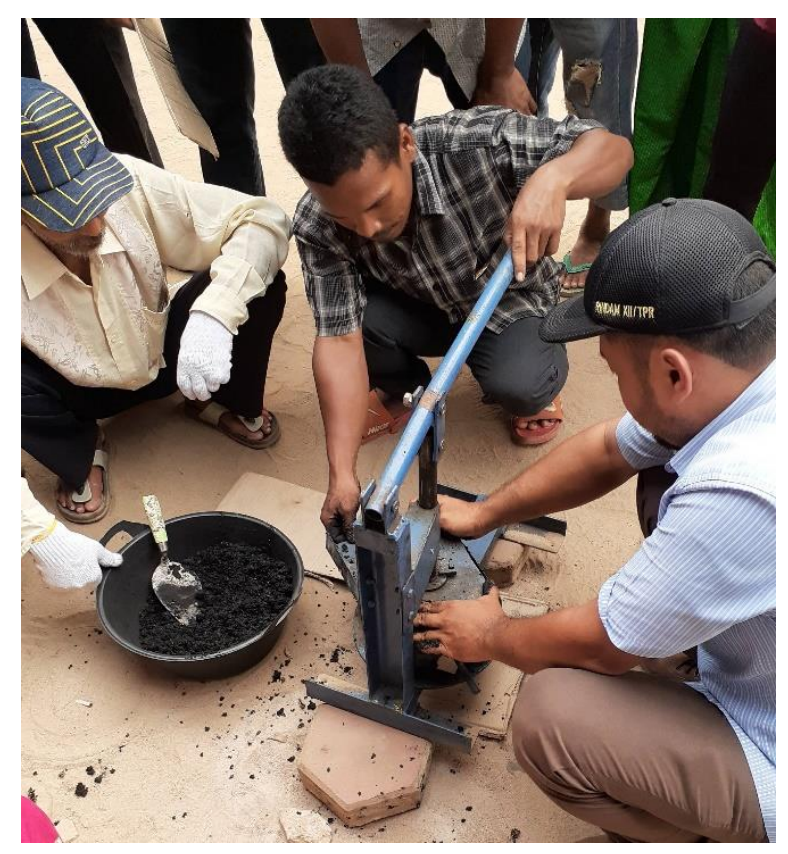

Gambar 4. Proses Pencetakan Briket 


\section{Evaluasi Pelaksanaan Kegiatan}

Evaluasi yang dilakukan pertama berupa kuesioner yang disebar kepada peserta PPM. Evaluasi ini dilakukan tepat setelah berlangsungnya kegiatan penyuluhan dan pelatihan pembuatan briket. Tujuan dari evalusi ini adalah untuk mengetahui berapa persen serapan pengetahuan dan keterampilan tentang inovasi setelah peserta mengikuti PPM serta manfaat materi yang diberikan bagi peserta. Berdasarkan hasil kuesioner yang disebar dan diisi oleh para peserta, menunjukkan bahwa sebesar $86 \%$ peserta peserta baru mengetahui informasi terkait pemanfaatan limbah jagung menjadi briket dan peserta sangat antusias untuk mencoba kembali setelah kegiatan selesai dilaksanakan. Selama ini limbah jagung (tongkol dan batang) tidak diolah menjadi sesuatu yang bernilai jual, adapun yang memberikannya kepada ternak sebagai pakan namun juga tidak melalui proses pengolahan lebih lanjut menjadi pakan ternak. Adanya PPM pelatihan pembuatan briket ini membuka wawasan para peserta untuk mengolah sesuatu di sekitarnya, terutama limbah yang melimpah untuk menjadi produk bernilai jual dan menambah penghasilan.

\section{Analisis Finansial}

Pembuatan briket ini dapat meningkatkan pendapatan petani. Jika dihitung dari arang hasil pembakaran yang telah dibentuk briket, 1 balok briket berukuran 55 gram. Produksi jagung di Kelurahan Sedau yaitu 4,3 ton/Ha dengan limbah yang dihasilkan yaitu 37\% sehingga diperoleh limbah sebanyak 1,591 ton/Ha. Jika diasumsikan bobot hilang hasil pembakaran sekitar 70\%, maka akan diperoleh sebanyak 477,3 Kg arang dari limbah jagung di Kelurahan ini. Untuk 1 kilo arang dan penambahan kanji sebagai perekat dapat menghasilkan 20 balok briket (berat briket $\pm 1 \mathrm{Kg}$ ). Harga $1 \mathrm{Kg}$ briket yaitu Rp. 8.000. Maka dalam panen $1 \mathrm{Ha}$ lahan jagung akan menghasilkan 447,3 Kg arang atau setara dengan 9.546 balok briket, jika dijual maka akan menghasilkan pendapatan kotor sebesar Rp. 3.818.400 dalam 1 kali panen. Jagung dapat panen sebanyak 3 kali dalam setahun, maka akan diperoleh Rp. 3.818 .400 x $3=\mathrm{Rp}$. 11.455.200.

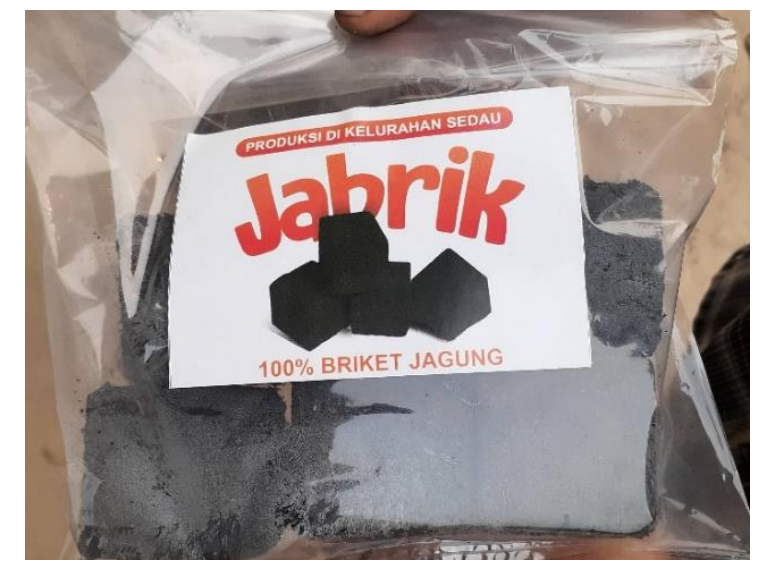

Gambar 5. Produk Briket yang dihasilkan dengan Merek Jabrik

\section{E. Evaluasi Lanjutan}

Evaluasi ini merupakan evaluasi lanjutan terhadap keberlanjutan dan keberhasilan program. Evaluasi dilakukan oleh Perwakilan Tim yaitu Bapak D.U.M Susilo yang langsung menemui Ketua Kelompok Tani JAS-B. Evaluasi ini bersifat sebagai kontrol terhadap kegiatan produksi briket serta menjaga terjalinnya silaturahim serta kerjasama dengan kelompok tani jagung di Kecamatan Sedau setelah kegiatan PPM selesai. Indikator keberhasilan yaitu 
terbentuknya usaha tani dalam pembuatan briket dari sisa panen dan pengolahan jagung di kecamatan Sedau. Berdasarkan informasi yang tim PPM Polnep peroleh, telah terbentuk Usaha Tani yang didirikan oleh anggota kelompok Tani JAS-B. Usaha ini bergerak dibidang ternak kambing, budidaya sayur-sayuran dan ditambah sedang melakukan pengembangan produk usaha barunya yaitu briket berbahan dasar limbah hasil panen/pengolahan jagung.

\section{Simpulan}

Hasil briket yang dihasilkan lebih baik teksturnya dibandingkan briket dari bahan baku lainnya. Seluruh peserta merasa tertarik untuk mencoba membuat produk briket dari limbah jagung, sebanyak 86\% peserta baru mengetahui informasi mengenai briket saat pelatihan oleh Tim PPM Polnep. Hasil analisis finansial dari pengolahan limbah jagung ini cukup potensial untuk meningkatkan perekonomian petani jagung di daerah Sedau. Perlu adanya pendampingan lanjutan untuk pembentukan UMKM dari Kelompok Tani ini dengan pengembangan produk usaha berasal dari limbah pertaniannya.

\section{Ucapan Terima Kasih}

Terima kasih penulis ucapkan kepada Unit Penelitian dan Pengabdian pada Masyarakat Politeknik Negeri Pontianak yang telah memfasilitasi pelaksanaan Program Pengabdian pada Masyarakat ini dengan pendanaan DIPA Polnep 2019

\section{Daftar Pustaka}

Balai Pengkajian Teknologi Pertanian NAD, 2009, Budidaya Tanaman Jagung, http://nad.litbang.pertanian.go.id/ind/images/dokumen/modul/27-Brosur\%20Jag/ diakses pada tanggal 4 Desember 2019.

BPS Kota Sigkawang, 2018, Singkawang Selatan dalam angka. https://singkawangkota.bps.go.id/publication/2018/08/16/ diakses pada tanggal 13 Juni 2019.

Ernita EJ., Yetti H., dan Ardian, 2017, Pengaruh Pemberian Limbah Serasah Jagung terhadap Pertumbuhan dan Produksi Jagung Manis (Zea mays), JOM Faperta Vol 4, No 2, Oktober 2017. 